\title{
(2) Omani experience with the use of factor IX Fc fusion protein \\ OPEN ACCESS
}

\author{
${ }^{1}$ School of Pharmacy, University \\ of London, London, UK \\ ${ }^{2}$ Clinical Pharmacy, Sultan \\ Qaboos University, Muscat, \\ Oman \\ ${ }^{3}$ Department of Child Health, \\ Sultan Qaboos University, \\ Muscat, Oman
}

\section{Correspondence to Shireen I Alzadjali; umhanifa@squ.edu.com}

Accepted 4 July 2021

\section{SUMMARY}

We describe our local experience in the management of haemophilia B patients with factor IX Fc fusion protein. Two children with haemophilia B were managed with the use of a personalised/tailored dosing schedule of factor IX Fc fusion protein. Compared with the standard halflife factor IX, prophylaxis with factor IX Fc fusion protein was cost-effective, with much less injections, better bleeding control, improved tolerability or no inhibitor development.

\section{BACKGROUND}

Haemophilia B is an $\mathrm{x}$-linked genetic disorder caused by missing or defective factor IX (FIX); it is also called FIX deficiency or Christmas disease. ${ }^{1}$ Although it is passed down from carrier females to their affected children, $33 \%$ of cases are due to spontaneous mutations. ${ }^{1}$

Disease severity depends on plasma level of FIX. Accordingly, haemophilia B is categorised as mild haemophilia B if level is between 5\% and $<40 \%$ and these patients experience bleeding only after serious injury, or trauma. Patients with moderate haemophilia B have FIX plasma level between 1\% and $5 \%$. They have occasional spontaneous bleeding or bleeding due to injury. Plasma level of FIX is $<1 \%$ in severe haemophilia B patients. They usually present with spontaneous bleeding into joints or muscles. ${ }^{2}$

FIX clotting concentrates whether plasma derived or recombinant products are used to treat haemophilia B. Plasma-derived clotting factor FIX concentrates continue to be used and are likely to remain an important therapeutic option for the foreseeable future. The administration of plasma-derived products is associated with a risk of pathogen transmission. However, this risk has been greatly reduced, if not virtually eliminated, by modern manufacturing techniques. ${ }^{3}$ Prophylactic treatment to prevent bleeding is the standard of care in patients with severe haemophilia B. Given that the half-life of standard recombinant FIX (rFIX) concentrate is around 18 hours, a biweekly infusion helps to sustain FIX level $>1 \%$ which reduces the risk of spontaneous bleeding. ${ }^{4}$ Since 2014 , thanks to advanced technologies, a new extended half-life FIX is available with a mean terminal half-life of 82-120 hours, ${ }^{5}$ this new product has significantly increased interinjection intervals.

In this context, we aim to illustrate our experience with long-acting FIX (Fc fusion protein, eftrenonacog alfa; Alprolix, Swedish Orphan Biovitrum $\mathrm{AB}$ (publ), Stockholm, Sweden). We report two educational case studies on haemophilia B patients who benefited from a tailored/personalised prophylaxis regimen of this agent.

\section{CASE PRESENTATION \\ Case one}

A boy born in May 2015 was referred to our department because of recurrent bruises of varying sizes and locations, easy oozing and prolonged bleeding. He was circumcised in the first week of life and experienced little oozing. His parents are not consanguineous with no family history of bleeding disorder. Following a coagulation test which showed a prolonged activated partial thromboplastin time (aPTT), he was diagnosed at the age of 8 months with severe haemophilia B (FIX assay $0.0029 \mathrm{U} / \mathrm{mL}$ ). The child's mother was counselled extensively about the disease's nature, its expected course and complications. Additionally, she was educated on keeping a safe home environment to prevent trauma. The medical staff also discussed with her the possibility of starting a prophylactic replacement therapy after 1 year of her child's life, in case he developed any joint bleeds.

At the age of 9 months, the child was readmitted because of an extensive muscular haematoma in the right hand and swelling and treated with fresh frozen plasma. Swelling did not subside and pain increased after 2 days of hospitalisation. Accordingly, he was given prothrombin complex (FII, FVII, FIX and FX). Afterwards, he experienced four more bleeding episodes at different sites and which were managed with local measures and prothrombin complex. At 19 months of life, the child was admitted with left buttocks bruises, and pain was managed with a single dose long-acting FIX (Fc fusion protein, eftrenonacog alfa; Alprolix, Swedish Orphan Biovitrum AB (publ), Stockholm, Sweden) at the dose of $1000 \mathrm{IU}$ $(84.7 \mathrm{IU} / \mathrm{kg})$. The child was administered the full vial of injection to prevent waste. At the age of 2 years, the child was admitted with gum bleeding managed again with one dose of long-acting FIX at $1000 \mathrm{IU}$ and tranexamic acid locally. Three months later in August 2017 at the age of 27 months, he was admitted in the paediatric intensive care unit with serious intra-peritoneal bleeding managed with packed red blood cell transfusion and long-acting FIX. Afterwards, prophylaxis with long-acting FIX at $1000 \mathrm{IU}(77 \mathrm{IU} / \mathrm{kg})$ was initiated every 10 days. $\mathrm{He}$ maintained a FIX trough level of $2.5 \%-3 \%$ with no further bleeding episodes during at least 3 years of follow-up (table 1). The same factor dose of $1000 \mathrm{IU}$ was maintained regardless of his weight. No inhibitors were detected with yearly Bethesda assays. 


\begin{tabular}{|c|c|c|c|}
\hline $\begin{array}{l}\text { Bleeding } \\
\text { episode }\end{array}$ & $\begin{array}{l}\text { Age before starting } \\
\text { on long-acting factor } \\
\text { IX Fc fusion protein }\end{array}$ & $\begin{array}{l}\text { On-demand } \\
\text { treatment with } \\
\text { long-acting factor } \\
\text { IX Fc fusion protein }\end{array}$ & $\begin{array}{l}\text { Prophylactic } \\
\text { treatment with long- } \\
\text { acting factor IX Fc } \\
\text { fusion protein }\end{array}$ \\
\hline 1. & 7 months & No & No \\
\hline 2. & 8 months & No & No \\
\hline 3. & 9 months & No & No \\
\hline 4. & 10 months & No & No \\
\hline 5. & 12 months & No & No \\
\hline 6. & 15 months & No & No \\
\hline 7. & 16 months & No & No \\
\hline 8. & 19 months & Yes & \\
\hline 9. & 22 months & Yes & No \\
\hline 10. & 24 months & Yes & No \\
\hline 11. & 27 months & Yes & $\begin{array}{l}\text { Yes (started on } \\
\text { prophylaxis) }\end{array}$ \\
\hline
\end{tabular}

\section{Case two}

A 6-month old boy was referred to our centre on September 2014 because of postcircumcision bleeding. The child had no medical history or bleeding episode (table 2). On first admission, the child was doing well, with minimal blood on banding around circumcision site, but no active bleeding was reported. Initially, haematology tests showed a prolonged aPTT of $52 \mathrm{~s}$ and a FIX level of $0.003 \mathrm{U} / \mathrm{mL}$ indicating a severe haemophilia B. All other factors were normal. Diagnostic workup of Von Willebrand disease was also performed. Given the absence of any active bleeding, the child was not given any treatment and was discharged. Later, he experienced three episodes of bleeding in different sites; the most serious episode was a scrotal haematoma for which he was given local and intravenous prothrombin complex.

On November 2015 at 20 months of life and after an episode of left ankle haemarthrosis, the child was started on long-acting FIX (Fc fusion protein, eftrenonacog alfa; Alprolix, Swedish Orphan Biovitrum AB (publ), Stockholm, Sweden) at $1000 \mathrm{IU}$ ( $90 \mathrm{IU} / \mathrm{kg}$; full vial to prevent waste) once every 10 days (table 3 ). On day 8 of treatment, FIX trough level was $9 \%$, so the clinical team decided to keep his prophylaxis every 2 weeks with monitoring trough levels. He had no further joint bleeds and the mother reported that he started to have bruises only after 3 weeks from the injections. His FIX trough was 3\% after 2

\begin{tabular}{|c|c|c|c|}
\hline $\begin{array}{l}\text { Bleeding } \\
\text { episode }\end{array}$ & $\begin{array}{l}\text { Age before } \\
\text { starting on long- } \\
\text { acting factor IX Fc } \\
\text { fusion protein }\end{array}$ & $\begin{array}{l}\text { On-demand } \\
\text { treatment with } \\
\text { long-acting factor } \\
\text { IX Fc fusion protein }\end{array}$ & $\begin{array}{l}\text { Prophylaxis } \\
\text { treatment with } \\
\text { long-acting factor } \\
\text { IX Fc fusion protein }\end{array}$ \\
\hline 1. & 6 months & No & No \\
\hline 2. & 11 months & No & No \\
\hline 3. & 15 months & No & No \\
\hline 4. & 19 months & No & No \\
\hline 5. & 20 months & No & $\begin{array}{l}\text { Yes (started on } \\
\text { prophylaxis) }\end{array}$ \\
\hline 6. & 22 months & $\begin{array}{l}\text { No (minor gun } \\
\text { bleeding managed } \\
\text { with local tranexamic } \\
\text { acid) }\end{array}$ & Yes \\
\hline
\end{tabular}

Table 3 Dosage, frequency and duration of prophylactic treatment with long-acting factor IX

\begin{tabular}{ll}
\hline From 12 November 2015 to 30 December 2015 & 1000 IU once every 10 days \\
\hline From 30 December 2015 to 25 October 2016 & 1000 IU once every 14 days \\
\hline 26 October 2016 to date & 1000 IU every 3 weeks \\
\hline
\end{tabular}

weeks then decreased to $2 \%$ after 3 weeks, from 26 October 2016 until.

Since then, the child has been taking regularly FIX Fc fusion (FIXF) protein, he is doing well and coming to the clinic on his schedule appointment. A Bethesda assay is performed every 12 months to measure inhibitors and no inhibitors were found. On 8 March 2020, the child was injured with minor bleeding. However, he experienced oozing as he needed three stitches in his chin; oozing stopped spontaneously. The child and his parents are happy with the effective prophylaxis plan of one injection every 3 weeks (one injection on day 20).

\section{DISCUSSION}

The current paper focusses on the management of haemophilia $\mathrm{B}$, and the initiation of prophylaxis with extended half-life rFIXF concentrate and its practical aspects by highlighting two illustrative case studies.

These two cases showed the pharmacokinetic differences between patients ${ }^{5}$ leading to using a different dose and interinjection interval of extended half-life FIX than recommended in the medication package insert. Patients' clinical response is an important factor in choosing the dosing schedule and intervals between injections.

It was clear that these two cases had significant bleeding episodes and burden on the family before starting the extended half-life FIX prophylaxis. In both cases, $\mathrm{Fc}$ fusion protein (eftrenonacog alfa; Alprolix, Swedish Orphan Biovitrum AB (publ), Stockholm, Sweden) was initiated after the boys bled significantly and one of them experienced a life-threatening bleeding episode. The prophylaxis with standard half-life product in the second case was not effective in preventing bleeding and was hindered by lack of compliance due to difficult venous access and the need for frequent injections in health centres away from home.

While bleeding can be effectively prevented with prophylactic treatment, some challenges are associated with the use of standard half-life FIX products. They require a high injection/ infusion frequency, often at least twice per week, because of the relatively short half-life. ${ }^{36}$ Consequently, patients' adherence to treatment may be negatively affected. ${ }^{6}$ Also, since young children have often poor venous access, frequent infusions can be difficult, painful and stressful for the children, their parents or caregivers. ${ }^{7}$ On the contrary, the innovative extended half-life FIX offered the patients more flexibility in terms of infusion timing. The two children received fewer injections which ensured better adherence, satisfaction and control over bleeding episodes. Long-acting FIX also allowed to maintain clotting factor activity at desired levels and up to the appropriate levels that meet the

\section{Learning points}

- Factor IX (FIX) Fc fusion protein is used to manage haemophilia B.

- It is cost-effective versus standard half-life FIX.

- It allows better dosing schedule and fewer injections. 
intensity of the patients' physical activities. Eventually, it helped the patients to start and/or maintain prophylaxis regimens with a personalised infusion schedule. ${ }^{8}$

Finally, treatment with extended half-life rFIXF protein is cost-effective as compared with the standard half-life FIX, especially with the use of a personalised/tailored dosing schedule with fewer injections.

Acknowledgements The authors thank the patients and their families for accepting the publication of the cases.

Contributors SIA: literature search, data acquisition, manuscript preparation, manuscript editing and manuscript review. YW: concept, patients care and follow-up, manuscript preparation, manuscript editing and manuscript review. Guarantors: both authors take responsibility for the integrity of the work as a whole from inception to published article. The manuscript has been read and approved by all the authors, requirements for authorship have been met, and each author believes that the manuscript represents honest work.

Funding This study was funded by SOBI (N/A).

Competing interests None declared.

Patient consent for publication Parental/guardian consent obtained.

Provenance and peer review Not commissioned; externally peer reviewed.

Open access This is an open access article distributed in accordance with the Creative Commons Attribution Non Commercial (CC BY-NC 4.0) license, which permits others to distribute, remix, adapt, build upon this work non-commercially, and license their derivative works on different terms, provided the original work is properly cited and the use is non-commercial. See: http://creativecommons.org/ licenses/by-nc/4.0/.

\section{ORCID iD}

Yasser Wali http://orcid.org/0000-0003-4275-4524

\section{REFERENCES}

1 National Hemophila Foundation. Bleeding disorder, types of bleeding disorder (hemophilia B), 2019. Available: https://www.hemophilia.org/Bleeding-Disorders/Typesof-Bleeding-Disorders/Hemophilia-B

2 Srivastava A, Brewer AK, Mauser-Bunschoten EP, et al. Guidelines for the management of hemophilia. Haemophilia 2013;19:e1-47.

3 Mannucci PM. Hemophilia therapy: the future has begun. Haematologica 2020;105:545-53.

4 Taylor JA, Kruse-Jarres R. A new era for hemophilia B treatment. Blood 2016;127:1734-6

5 Graf L. Extended half-life factor VIII and factor IX preparations. Transfus Med Hemother 2018:45:86-91.

6 Ahmed S, Zhou Z, Zhou J, et al. Pharmacogenomics of drug metabolizing enzymes and transporters: relevance to precision medicine. Genomics Proteomics Bioinformatics 2016;14:298-313.

7 Lambert T, Benson G, Dolan G, et al. Practical aspects of extended half-life products for the treatment of haemophilia. Ther Adv Hematol 2018;9:295-308.

8 Cuker A. Long-acting factor concentrates for hemophilia. In: The Hematologist ash news and reports. 12. 1 edn. Washington, DC: American Society of Hematology, 2015.

Copyright 2021 BMJ Publishing Group. All rights reserved. For permission to reuse any of this content visit

https://www.bmj.com/company/products-services/rights-and-licensing/permissions/

BMJ Case Report Fellows may re-use this article for personal use and teaching without any further permission.

Become a Fellow of BMJ Case Reports today and you can:

- Submit as many cases as you like

- Enjoy fast sympathetic peer review and rapid publication of accepted articles

- Access all the published articles

Re-use any of the published material for personal use and teaching without further permission

\section{Customer Service}

If you have any further queries about your subscription, please contact our customer services team on +44 (0) 2071111105 or via email at support@bmj.com.

Visit casereports.bmj.com for more articles like this and to become a Fellow 